\title{
5 Research Square

\section{Ga-labeled ODAP-Urea-based PSMA Agents in Prostate Cancer: First-in-human Imaging of an Optimized Agent}

\section{Xiaojiang Duan}

Peking University First Hospital

\section{Zhen Cao}

Peking University First Hospital

Hua Zhu

Peking University Cancer Hospital \&amp; Institute

Chen Liu

Peking University Cancer Hospital \&amp; Institute

\section{Xiaojun Zhang}

The First Medical Center of Chinese PLA General Hospital

\section{Jinming Zhang}

The First Medical Center of Chinese PLA General Hospital

\section{Yanan Ren}

Peking University Cancer Hospital \&amp; Institute

\section{Futao Liu}

Peking University Cancer Hospital \&amp; Institute

\section{Xuekang Cai}

Peking University First Hospital

\section{Xiaoyi Guo}

Peking University Cancer Hospital \&amp; Institute

\section{Zhen Xi}

Nankai University

\section{Martin G.Pomer}

Johns Hopkins Medical Institutions

\section{Zhi Yang}

Peking University Cancer Hospital \&amp; Institute

\section{Yan Fan ( $\nabla$ fanyan980618@sina.com )}

Peking University First Hospital

\section{Xing Yang}

Peking University First Hospital 


\section{Research Article}

Keywords: Prostate-specific membrane antigen, tumor-bearing mice, ODAP-Urea-based ligands

Posted Date: March 31st, 2021

DOl: https://doi.org/10.21203/rs.3.rs-364739/v1

License: (c) (i) This work is licensed under a Creative Commons Attribution 4.0 International License. Read Full License

Version of Record: A version of this preprint was published at European Journal of Nuclear Medicine and Molecular Imaging on August 28th, 2021. See the published version at https://doi.org/10.1007/s00259021-05486-x. 


\section{Supporting information}

\section{${ }^{68}$ Ga-Labeled ODAP-Urea-based PSMA Agents in Prostate Cancer:}

\section{First-in-human Imaging of An Optimized Agent}

Xiaojiang Duan ${ }^{1}$, Zhen $\mathrm{Cao}^{1}$, Hua Zhu², Chen $\mathrm{Liu}^{2}$, Xiaojun Zhang ${ }^{3}$, Jinming Zhang ${ }^{3}$, Ya'nan Ren²,

Futao Liu ${ }^{2}$, Xuekang Cai ${ }^{1}$, Xiaoyi Guo ${ }^{2}$, Zhen Xi ${ }^{4}$, Martin G. Pomper ${ }^{5}$, Zhi Yang ${ }^{2, *}$, Yan Fan ${ }^{1, *}$, Xing Yang $1,6, *$

${ }^{1}$ Department of Nuclear Medicine, Peking University First Hospital, Beijing, 100034, China.

${ }^{2}$ Department of Nuclear Medicine, Peking University Cancer Hospital \& Institute, Beijing 100142, China.

${ }^{3}$ Department of Nuclear Medicine, the First Medical Center of Chinese PLA General Hospital, Beijing 100853, China.

${ }^{4}$ State Key Laboratory of Elemento-Organic Chemistry and Department of Chemical Biology,

National Pesticide Engineering Research Center, Nankai University, Tianjin, 300071, China.

${ }^{5}$ Russell H. Morgan Department of Radiology and Radiological Science, Johns Hopkins Medical Institutions, Baltimore, MD 21287, USA.

${ }^{6}$ Institute of Medical Technology, Peking University Health Science Center, Beijing, 100191, China

Corresponding Author:

Xing Yang, Tel: 8610 83572928; Email: yangxing2017@bjmu.edu.cn

Yan Fan, Tel: 8610 83572791; E-mail: fanyan980618@ sina.com; fanyan@bjmu.edu.cn

Zhi Yang, Tel: 8610 88196196; Email: pekyz@163.com

Xiaojiang Duan, Zhen Cao and Hua Zhu contribute equally to this work. 


\section{Table of Contents}

1. Preparation of the ligands 3

2. PSMA inhibition results of the ligands tested 8

3. Radiolabeling yield and $\log P$ of ${ }^{68}$ Ga-labeled compounds 9

4. MicroPET imaging studies and biodistribution 10

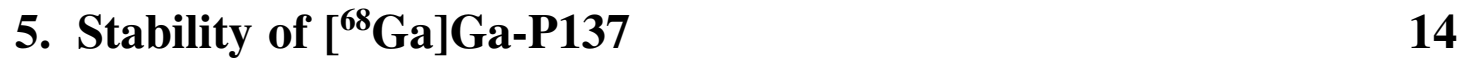

6. Abnormal toxicity test 14

7. SUV of translational PET/CT Imaging 15 


\section{Preparation of the ligands}

\section{General}

All solvents and chemicals purchased from commercial sources were analytical grade or better and were used without further purification. The final products and key intermediates were characterized with mass spectrometry (MS). High performance liquid chromatography (HPLC) analysis was performed using a Venusil MP C18 $4.60 \times 150 \mathrm{~mm}^{2}$ column (Bonna-Agela Technologies, Tianjin, China) on a FL-LC010G chromatography system (Bonna-Agela Technologies, Tianjin, China) with solvent gradient A (water with $0.1 \%$ trifluoroacetic acid) and gradient B (acetonitrile with $0.1 \%$ trifluoroacetic acid) at a flow rate of $0.8 \mathrm{~mL} / \mathrm{min}$. The analytical HPLC condition was gradient of 5-95\% B over $5 \mathrm{~min}$ and $95 \% \mathrm{~B}$ for another $10 \mathrm{~min}$, and the retention times were reported. Preparative HPLC purifications were performed using a Phenomenex C18 Luna $10.0 \times 250 \mathrm{~mm}^{2}$ column on a FL-H050G preparative chromatography system (Bonna-Agela Technologies, Tianjin, China). The products were eluted using eluent $\mathrm{A}$ (water with $0.1 \%$ trifluoroacetic acid) and eluent B (acetonitrile with $0.1 \%$ trifluoroacetic acid) at a flow rate of $4 \mathrm{~mL} / \mathrm{min}$.

\section{Synthesis of PSMA ligands P117-126}

All the ligands were synthesized via solid-phase synthesis which was performed according to Fmoc peptide synthesis protocol. The synthesis cycle consisted of: i) Fmoc cleavage: 20\% piperidine in $N, N$-dimethylformamide (DMF), ii) DMF washings, iii) coupling, and iv) DMF washings. The resin was treated with $2 \mathrm{~mL}$ dichloromethane (DCM) for $5 \mathrm{~min}$ three times and $2 \mathrm{~mL}$ DMF for $5 \mathrm{~min}$ three times before used. The resin was washed thoroughly before it was incubated with HBTUpreactivated amino acid, amino acid derivatives or tris-tBu-DOTA. DDE was cleaved by $2 \%$ hydrazine hydrate/DMF for 3 min twice. Cleavage from the solid support was performed with trifluoroacetic acid (TFA)/water/triisopropylsilane $(95 / 2.5 / 2.5$, vol $/ \mathrm{vol} / \mathrm{vol})$ over $3 \mathrm{~h}$ at room temperature. The products were purified by HPLC. The synthesis routes of P117-126 were shown in Figure S1. 


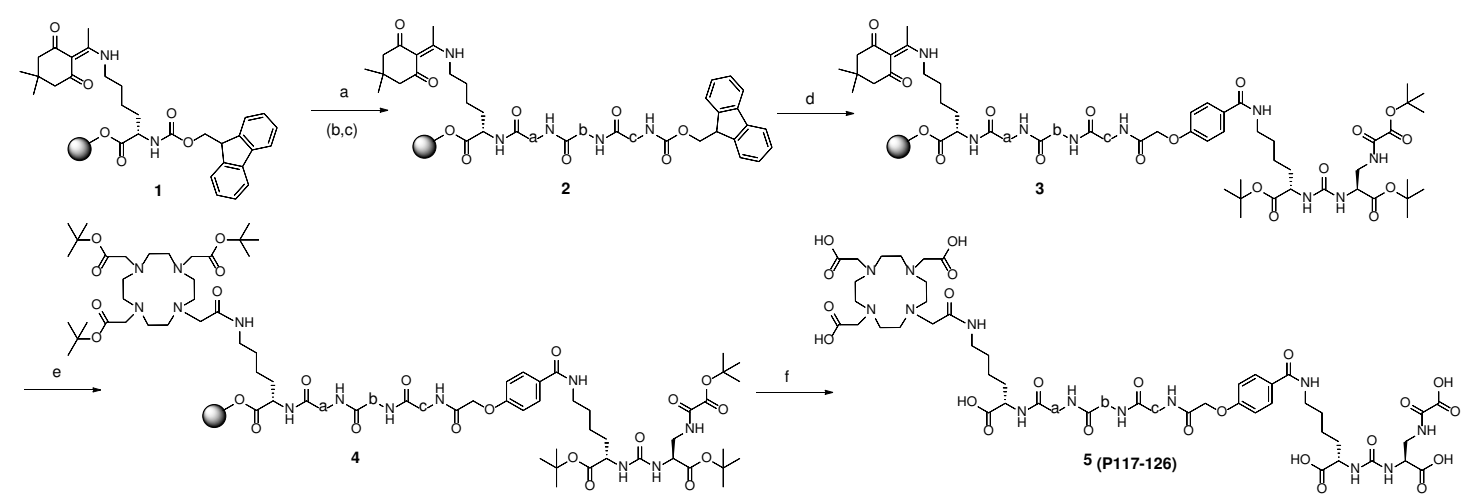

Figure S1. Synthesis of P117-126. a: 20\% piperidine in DMF deprotection, and then DMF solutions of Fmoc-a-OH, HBTU, HOBt and DIPEA; b: 20\% piperidine in DMF deprotection, and then DMF solutions of Fmoc-b-OH, HBTU, HOBt and DIPEA; c: 20\% piperidine in DMF deprotection, and then DMF solutions of Fmoc-c-OH, HBTU, HOBt and DIPEA; d: $20 \%$ piperidine in DMF deprotection, and then DMF solutions of 12, HBTU, HOBt and DIPEA; e: 20\% piperidine in DMF deprotection, and then DMF solutions of DOTA (2-(4,7,10-tris(2-(tert-butoxy)-2-oxoethyl)1,4,7,10-tetraazacyclododecan-1-yl)acetic acid), HBTU, HOBt and DIPEA; f: trifluoroacetic acid/ triisopropylsilane/water.

Compound 12 used by P117-126 was synthesized according to the procedures shown in Figure S2. Benzyl 2-bromoacetate (6, $3.44 \mathrm{~g}, 15 \mathrm{mmol})$ and tert-Butyl 4-hydroxybenzoate (7, $2.43 \mathrm{~g}, 12.5$ mmol) were dissolved in DMF (20 mL). Potassium carbonate $(2.76 \mathrm{~g}, 20 \mathrm{mmol})$ was added to the solution. The mixture was stirred at $60{ }^{\circ} \mathrm{C}$ for $5 \mathrm{~h}$. The reaction mixture was filtered and washed with DCM (100 mL). After the solvent was removed under vacuum, $8(3.7 \mathrm{~g}, 86 \%)$ was obtained after silica gel flash column chromatography. The obtained $\mathbf{8}$ was dissolved in DCM (10 mL) and TFA $(10 \mathrm{~mL})$, and stirred at room temperature for $5 \mathrm{~h}$. After the solvent was removed under vacuum, 9 was obtained. 9 (3.1 g, $10.8 \mathrm{mmol})$, 1-(3-dimethylaminopropyl)-3-ethylcarbodiimide hydrochloride (EDCI, $2.74 \mathrm{~g}, 14.3 \mathrm{mmol}$ ) and $N$-hydroxysuccinimide (NHS, $1.65 \mathrm{~g}, 14.3 \mathrm{mmol}$ ) were dissolved in DMF $(50 \mathrm{~mL})$ and the mixture was stirred at room temperature for $12 \mathrm{~h}$. After the solvent was removed under vacuum, $10(1.18 \mathrm{~g}, 28 \%)$ was obtained after silica gel flash column chromatography. 10 (1.18 g, $3.1 \mathrm{mmol})$ and (S)-tert-Butyl 6-Amino-2-(3-((S)-1-(tert-butoxy)-3-(2(tert-butoxy)-2-oxoacetamido)-1-oxopropan-2-yl)-ureido) hexanoate (1.33g $2.57 \mathrm{mmol})(\mathrm{J} . \mathrm{Med}$. Chem. 2020, 63, 3563-3573) were dissolved in DMF (20 mL) and $N, N$-diisopropylethylamine (DIPEA) was added to the solution. The solution was stirred at room temperature for $12 \mathrm{~h}$ and after 
the solvent was removed under vacuum, $\mathbf{1 1}(1.95 \mathrm{~g}, 82 \%)$ was obtained after silica gel flash column chromatography. 11 (700 mg, $0.89 \mathrm{mmol})$ and 10\% dry Pd/C (50 mg) were mixed in $\mathrm{MeOH}(20 \mathrm{~mL})$ under $\mathrm{H}_{2}$ and stirred at room temperature for $12 \mathrm{~h}$. After filtration, the solvent was removed under vacuum and $12(500 \mathrm{mg}, 81 \%)$ was obtained after silica gel flash column chromatography as a colorless oil. The MS data of all the key compounds were shown as follows (Table S1)
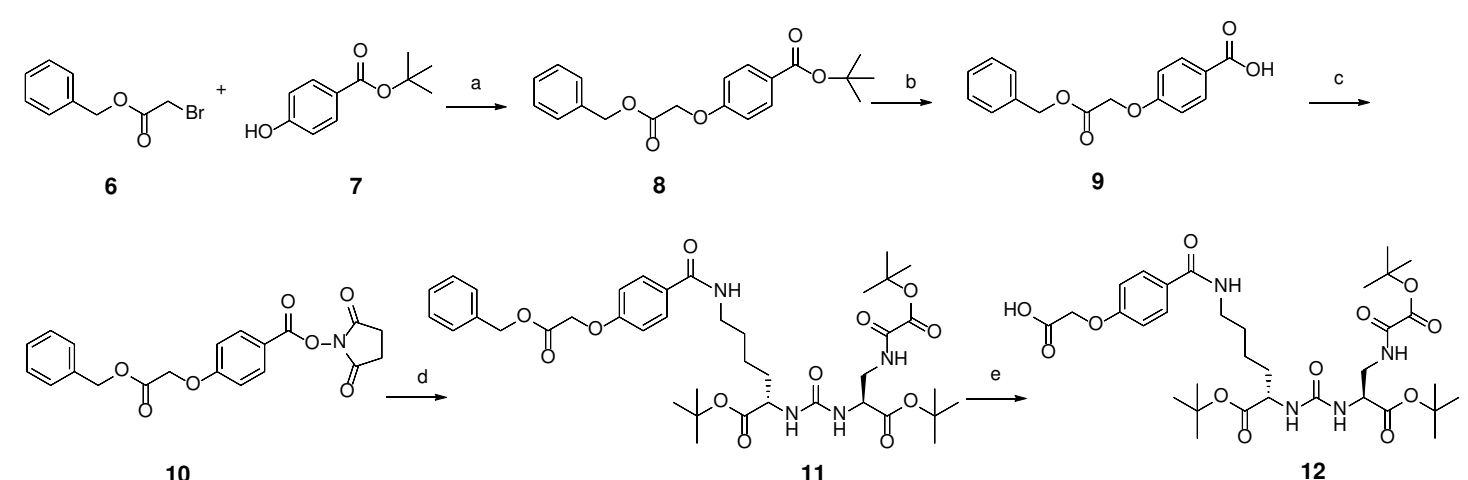

10

Figure S2. Synthesis of 12. a: $\mathrm{K}_{2} \mathrm{CO}_{3}$, DMF, $60{ }^{\circ} \mathrm{C}$; b: TFA, DCM; c: EDCI, NHS, DMF; d: $(S)$ tert-Butyl 6-Amino-2-(3-((S)-1-(tert-butoxy)-3-(2-(tert-butoxy)-2-oxoacetamido)-1-oxopropan-2yl)-ureido)hexanoate, DMF, DIPEA; e: $\mathrm{Pd} / \mathrm{C}, \mathrm{H}_{2}, \mathrm{MeOH}$.

\section{Synthesis of PSMA ligands P136-P144}

The synthesis routes of the P136-144 were shown in Figure S3, with procedures similar to P117. The resin $\mathbf{1 3}$ was prepared from the key intermediate $\mathbf{2 1}$ as shown in Figure $\mathbf{S 4}$. Triphosgene (122 $\mathrm{mg}, 0.41 \mathrm{mmol})$ was dissolved in anhydrous DCM $(30 \mathrm{~mL})$ at $-10{ }^{\circ} \mathrm{C}$. To the solution, a mixture of $17(500 \mathrm{mg}, 1.229 \mathrm{mmol})$ and $\mathrm{Et}_{3} \mathrm{~N}(428 \mu \mathrm{L}, 3.07 \mathrm{mmol})$ in anhydrous DCM $(15 \mathrm{~mL})$ was added over $30 \mathrm{~min}$. The mixture was stirred at $-10{ }^{\circ} \mathrm{C}$ for $2 \mathrm{~h}$, and then a solution of compound $\mathbf{1 8}$ (354 mg, 1.229 mmol) (J. Med. Chem. 2020, 63, 3563-3573) and $\mathrm{Et}_{3} \mathrm{~N}(206 \mu \mathrm{L}, 6.38 \mathrm{mmol})$ in anhydrous DCM $(20 \mathrm{~mL})$ was added. The reaction was stirred for another $1 \mathrm{~h}$. After the solvent was removed under vacuum, 19 (614mg, 73\%) was obtained after silica gel flash column chromatography as a colorless oil. A mixture of $\mathbf{1 9}$ (614 mg, $0.89 \mathrm{mmol})$ and $10 \%$ dry Pd/C was stirred in $\mathrm{MeOH}(30 \mathrm{~mL})$ under $\mathrm{H}_{2}$ for $12 \mathrm{~h}$ at room temperature. The reaction mixture was filtered and washed with $\mathrm{MeOH}$ $(10 \mathrm{~mL})$ and $\mathrm{DCM}(10 \mathrm{~mL})$. The solvent was removed under vacuum to get $\mathbf{2 0}(410 \mathrm{mg}, 83 \%)$ as a colorless oil and $\mathbf{2 0}$ was used for next step without further purification. 20 (410 mg, $0.735 \mathrm{mmol})$ was dissolved in 1,4-dioxane $/ \mathrm{H}_{2} \mathrm{O}\left(20 \mathrm{~mL}, 2.5 / 1\right.$, vol/vol). $\mathrm{NaHCO}_{3}(252 \mathrm{mg}, 3 \mathrm{mmol})$ and Fmoc- 
$\mathrm{Cl}(228 \mathrm{mg}, 0.882 \mathrm{mmol})$ were added to the solution and stirred for $10 \mathrm{~min}$ at room temperature. The reaction mixture was filtered and extracted with ethyl acetate $(10 \mathrm{~mL})$. After the solvent was removed under vacuum, 21 (290 mg, 59\%) was obtained after silica gel flash column chromatography. 2-CTC resin $(1 \mathrm{~g})$ was added to DCM $(10 \mathrm{~mL})$ and the solution was stirred for $1 \mathrm{~h}$. After the solvent was removed, 21 (290 mg, $0.43 \mathrm{mmol})$ and DMF/DCM (10 ml, 1/1, vol/vol) were stirred for $3 \mathrm{~h}$ at room temperature. DCM/MeOH/DIPEA (10/10/1, vol/vol/vol) was used four times for blocking the excess reactive sites on 2-CTC resin. Finally, $1.2 \mathrm{~g}$ of $\mathbf{1 3}$ was obtained. The MS data of all the key compounds were shown as follows (Table S1)

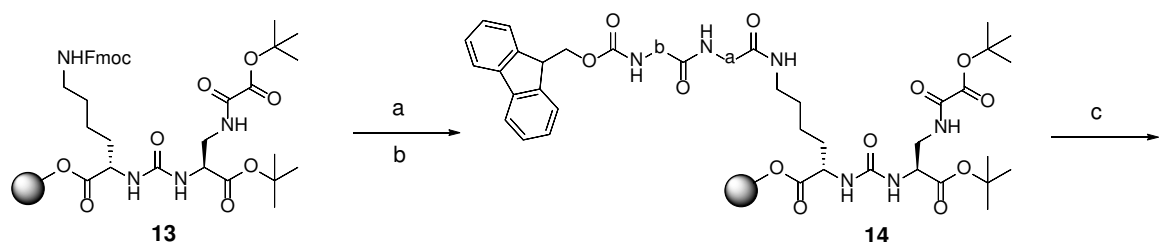

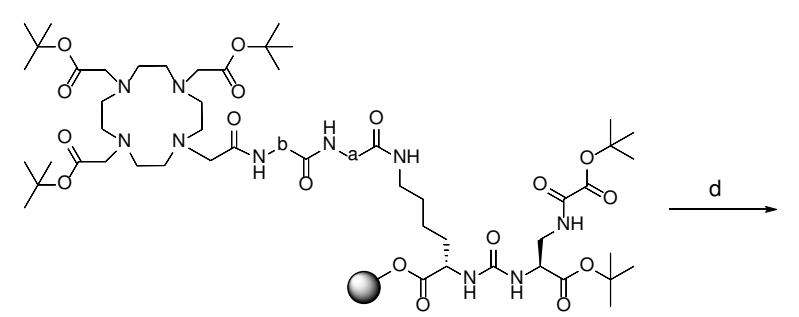

15

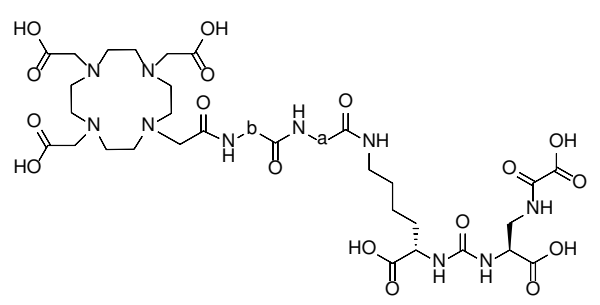

16(P136-144)

Figure S3. Synthesis of P136-144. a: 20\% piperidine in DMF deprotection, and then DMF solutions of Fmoc-a-OH, HBTU, HOBt and DIPEA; b: $20 \%$ piperidine in DMF deprotection, and then DMF solutions of Fmoc-b-OH, HBTU, HOBt and DIPEA; c: $20 \%$ piperidine in DMF deprotection, and then DMF solutions of DOTA (2-(4,7,10-tris(2-(tert-butoxy)-2-oxoethyl)-1,4,7,10tetraazacyclododecan-1-yl)acetic acid), HBTU, HOBt and DIPEA; d: trifluoroacetic acid/ triisopropylsilane/water. 

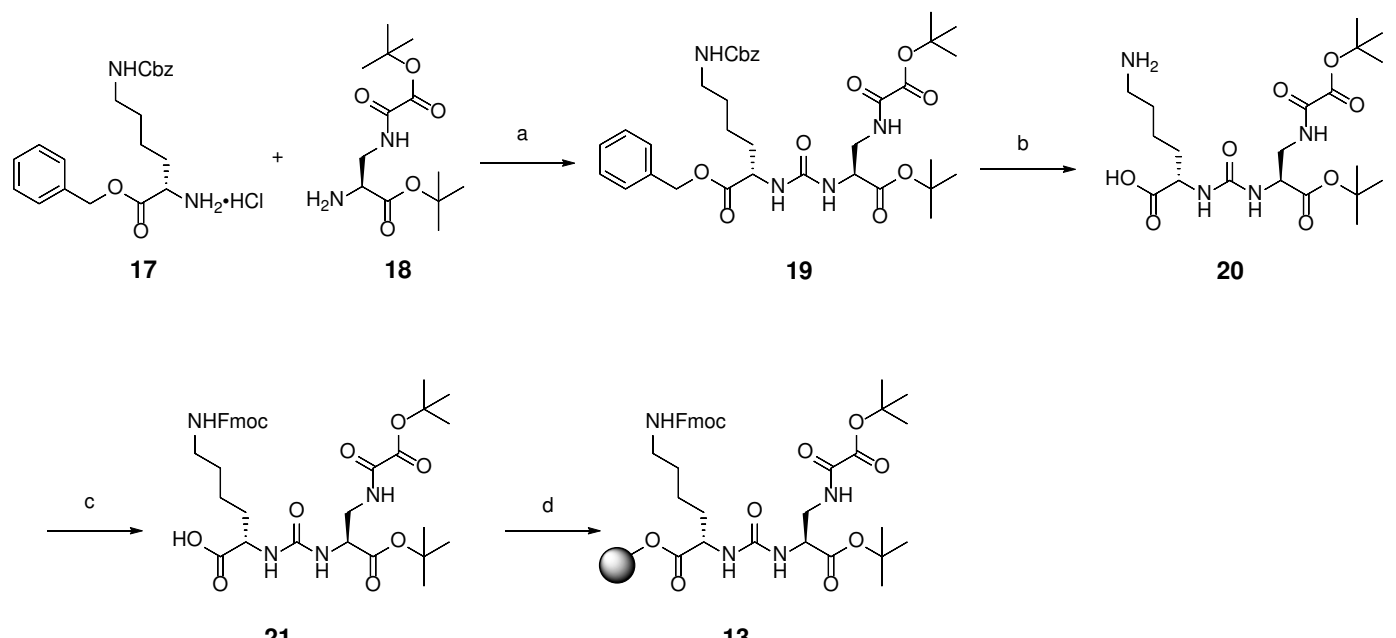

21

13

Figure S4. Synthesis of 13. a: DCM, Et $t_{3} \mathrm{~N}$, triphosgene; b: $\mathrm{Pd} / \mathrm{C}, \mathrm{H}_{2}, \mathrm{MeOH}$; c: $\mathrm{Fmoc}-\mathrm{Cl}, \mathrm{NaHCO}_{3}$, 1,4-dioxane, $\mathrm{H}_{2} \mathrm{O}$; d: 2-CTC resin, DMF, DCM, MeOH, DIPEA.

Table S1. Results of the identification of compounds by LC-MS.

\begin{tabular}{|c|c|c|c|c|c|}
\hline \multirow[b]{2}{*}{ Compound } & \multirow[b]{2}{*}{ Sum formula } & \multirow{2}{*}{$\begin{array}{c}R_{\mathrm{t}}(\mathrm{HPLC} \\
\text { analysis, } \\
\text { min })\end{array}$} & \multirow{2}{*}{$\begin{array}{l}\text { Yield of } \\
\text { chemical } \\
\text { synthesis }\end{array}$} & \multicolumn{2}{|l|}{$[\mathrm{M}]$} \\
\hline & & & & (calc.) & (found) \\
\hline 12 & $\mathrm{C}_{33} \mathrm{H}_{50} \mathrm{~N}_{4} \mathrm{O}_{12}$ & --- & $81.0 \%$ & $694.34[\mathrm{M}+\mathrm{H}]^{+}$ & 695.40 \\
\hline P117 & $\mathrm{C}_{51} \mathrm{H}_{77} \mathrm{~N}_{11} \mathrm{O}_{21}$ & 5.853 & $14.2 \%$ & $1179.53[\mathrm{M}-\mathrm{H}]^{-}$ & 1178.40 \\
\hline $\mathrm{P} 120$ & $\mathrm{C}_{60} \mathrm{H}_{86} \mathrm{~N}_{12} \mathrm{O}_{22}$ & 6.188 & $12.9 \%$ & $1365.56[\mathrm{M}+\mathrm{K}]^{+}$ & 1365.80 \\
\hline $\mathrm{P} 122$ & $\mathrm{C}_{56} \mathrm{H}_{80} \mathrm{~N}_{12} \mathrm{O}_{22}$ & 6.062 & $19.0 \%$ & $1311.51[\mathrm{M}+\mathrm{K}]^{+}$ & 1311.75 \\
\hline $\mathrm{P} 123$ & $\mathrm{C}_{64} \mathrm{H}_{80} \mathrm{~N}_{12} \mathrm{O}_{22}$ & 6.373 & $13.3 \%$ & $1407.52[\mathrm{M}+\mathrm{K}]^{+}$ & 1407.60 \\
\hline P124 & $\mathrm{C}_{60} \mathrm{H}_{82} \mathrm{~N}_{12} \mathrm{O}_{22}$ & 6.238 & $12.3 \%$ & $1361.53[\mathrm{M}+\mathrm{K}]^{+}$ & 1361.65 \\
\hline P125 & $\mathrm{C}_{65} \mathrm{H}_{89} \mathrm{~N}_{13} \mathrm{O}_{23}$ & 6.220 & $12.1 \%$ & $1458.58[\mathrm{M}+\mathrm{K}]^{+}$ & 1458.85 \\
\hline P126 & $\mathrm{C}_{65} \mathrm{H}_{89} \mathrm{~N}_{13} \mathrm{O}_{23}$ & 6.202 & $12.3 \%$ & $1458.58[\mathrm{M}+\mathrm{K}]^{+}$ & 1458.60 \\
\hline 21 & $\mathrm{C}_{35} \mathrm{H}_{46} \mathrm{~N}_{4} \mathrm{O}_{10}$ & ---- & $57.8 \%$ & $683.33[\mathrm{M}+\mathrm{H}]^{+}$ & 683.40 \\
\hline P136 & $\mathrm{C}_{49} \mathrm{H}_{70} \mathrm{~N}_{10} \mathrm{O}_{17}$ & 6.240 & $28.8 \%$ & $1071.50[\mathrm{M}+\mathrm{H}]^{+}$ & 1071.70 \\
\hline P137 & $\mathrm{C}_{49} \mathrm{H}_{64} \mathrm{~N}_{10} \mathrm{O}_{17}$ & 6.273 & $44.4 \%$ & $1065.45[\mathrm{M}+\mathrm{H}]^{+}$ & 1065.65 \\
\hline P141 & $\mathrm{C}_{45} \mathrm{H}_{61} \mathrm{~N}_{10} \mathrm{O}_{17}$ & 6.280 & $44.1 \%$ & $1179.29[\mathrm{M}+\mathrm{K}]^{+}$ & 1178.75 \\
\hline $\mathrm{P} 143$ & $\mathrm{C}_{51} \mathrm{H}_{66} \mathrm{~N}_{10} \mathrm{O}_{17}$ & 6.395 & $34.4 \%$ & $1129.42[\mathrm{M}+\mathrm{K}]^{+}$ & 1128.90 \\
\hline P144 & $\mathrm{C}_{45} \mathrm{H}_{64} \mathrm{~N}_{10} \mathrm{O}_{17}$ & 6.160 & $36.0 \%$ & $1055.41[\mathrm{M}+\mathrm{K}]^{+}$ & 1054.85 \\
\hline
\end{tabular}




\section{PSMA inhibition results of the ligands tested}
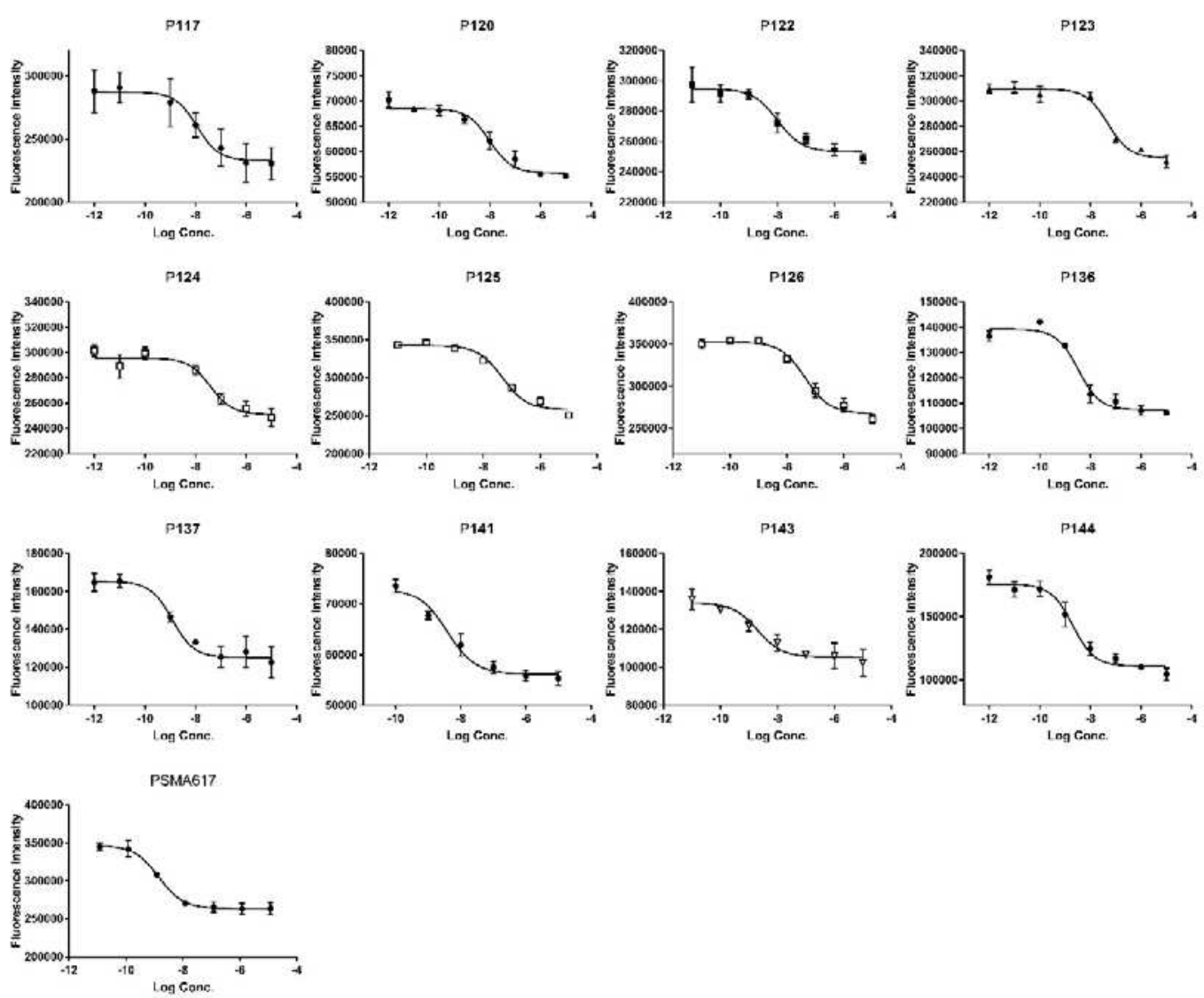

Figure S5. Inhibition curves of P117-P144 and PSMA617 using a fluorescence-based NAALADase assay. 


\section{Radiolabeling yield and $\log P$ of ${ }^{68}$ Ga-labeled compounds}

Radiolabeling: ${ }^{68} \mathrm{GaCl}_{3}$ was obtained from a ${ }^{68} \mathrm{Ge} /{ }^{68} \mathrm{Ga}$ generator (maximum production 1.85 GBq, ITG, Germany). The preparation of ${ }^{68} \mathrm{Ga}$-labeled compounds was carried out according to the following general procedure. After optimization, $30 \mu \mathrm{g}$ of each ligand was incubated with a mixture of $1.0 \mathrm{~mL}^{68} \mathrm{GaCl}_{3}(0.05 \mathrm{~N} \mathrm{HCl})$ eluent with radioactivity of $185-370 \mathrm{MBq}$ and $65 \mu \mathrm{L}$ sodium acetate $\left(1 \mathrm{~mol} / \mathrm{L}\right.$ ) at $85-90{ }^{\circ} \mathrm{C}$ for $10 \mathrm{~min}$. The product was purified by a Sep-Pak ${ }^{\circledR}$ Light $\mathrm{C} 18$ cartridge (Waters, Milford, Massachusetts, USA) and the ${ }^{68} \mathrm{Ga}$-labeled compound was obtained by eluting the cartridge with $0.6 \mathrm{~mL} 80 \%$ ethanol. After diluting with saline and passing through a $0.2 \mu \mathrm{m}$ sterile filter (Merck Millipore, Darmstadt, Germany), the formulation was applied to the imaging study. The radiochemical purity (RCP) of ${ }^{68} \mathrm{Ga}$-labeled compounds was analyzed by radio-HPLC (Shimadzu LC-20A, Japan; Flow-Count, Eckert\&Ziegler, Germany).

Table S2. RCPs before and after purified and $\log P$ values of ${ }^{68} \mathrm{Ga}$-labeled compounds.

\begin{tabular}{|c|c|c|c|}
\hline $\begin{array}{l}{ }^{68} \mathrm{Ga} \text {-Labeled } \\
\text { compounds }\end{array}$ & $\begin{array}{l}\text { RCPs before purified } \\
\text { (repeat times) }\end{array}$ & RCPs after purified & $\log P$ \\
\hline$\left[{ }^{68} \mathrm{Ga}\right] \mathrm{Ga}-\mathrm{P} 117$ & $92 \%-95 \%(3)$ & $>98 \%$ & $-2.15 \pm 0.17$ \\
\hline$\left[{ }^{68} \mathrm{Ga}\right] \mathrm{Ga}-\mathrm{P} \mathbf{1 2 0}$ & $90 \%-95 \%(3)$ & $>98 \%$ & $-2.48 \pm 0.10$ \\
\hline$\left[{ }^{68} \mathrm{Ga}\right] \mathrm{Ga}-\mathrm{P} \mathbf{1 2 2}$ & $90 \%-96 \%(3)$ & $>98 \%$ & $-1.05 \pm 0.09$ \\
\hline$\left[{ }^{68} \mathrm{Ga}\right] \mathrm{Ga}-\mathrm{P} \mathbf{1 2 3}$ & $89 \%-93 \%(3)$ & $>98 \%$ & $-1.22 \pm 0.06$ \\
\hline$\left[{ }^{68} \mathrm{Ga}\right] \mathrm{Ga}-\mathrm{P} \mathbf{1 2 4}$ & $90 \%-94 \%(3)$ & $>98 \%$ & $-1.87 \pm 0.04$ \\
\hline$\left[{ }^{68} \mathrm{Ga}\right] \mathrm{Ga}-\mathrm{P} 125$ & $91 \%-95 \%(3)$ & $>98 \%$ & $-1.10 \pm 0.05$ \\
\hline$\left[{ }^{68} \mathrm{Ga}\right] \mathrm{Ga}-\mathrm{P} \mathbf{1 2 6}$ & $90 \%-95 \%(3)$ & $>98 \%$ & $-0.79 \pm 0.08$ \\
\hline$\left[{ }^{68} \mathrm{Ga}\right] \mathrm{Ga}-\mathrm{P} 136$ & $91 \%-96 \%(3)$ & $>98 \%$ & $-2.62 \pm 0.30$ \\
\hline$\left[{ }^{68} \mathrm{Ga}\right] \mathrm{Ga}-\mathrm{P} 137$ & $92 \%-97 \%(>10)$ & $>99 \%$ & $-2.48 \pm 0.18$ \\
\hline$\left[{ }^{68} \mathrm{Ga}\right] \mathrm{Ga}-\mathrm{P} 141$ & $90 \%-96 \%(3)$ & $>98 \%$ & $-1.19 \pm 0.24$ \\
\hline$\left[{ }^{68} \mathrm{Ga}\right] \mathrm{Ga}-\mathrm{P} \mathbf{1 4 3}$ & $91 \%-96 \%(3)$ & $>98 \%$ & $-1.46 \pm 0.08$ \\
\hline$\left[{ }^{68} \mathrm{Ga}\right] \mathrm{Ga}-\mathrm{P} 144$ & $92 \%-97 \%(3)$ & $>98 \%$ & $-1.84 \pm 0.07$ \\
\hline${ }^{68}$ Ga-PSMA-617 & $92 \%-98 \%(5)$ & $>99 \%$ & $-2.00 \pm 0.27$ \\
\hline
\end{tabular}


4. MicroPET imaging studies and biodistribution

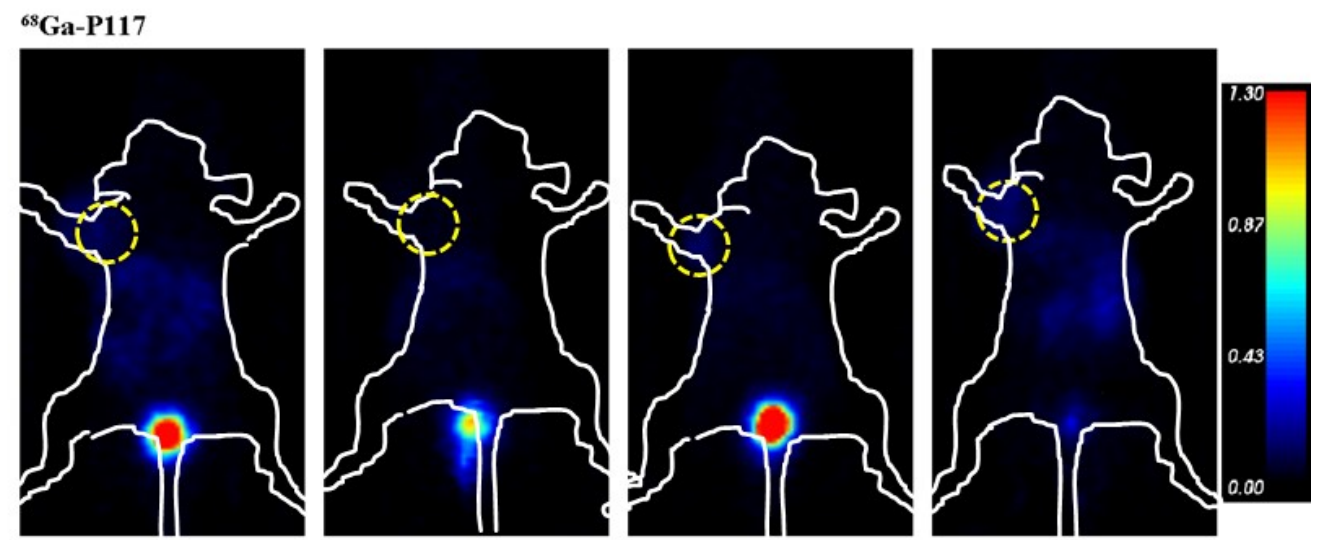

${ }^{68} \mathrm{Ga}-\mathrm{P} 120$
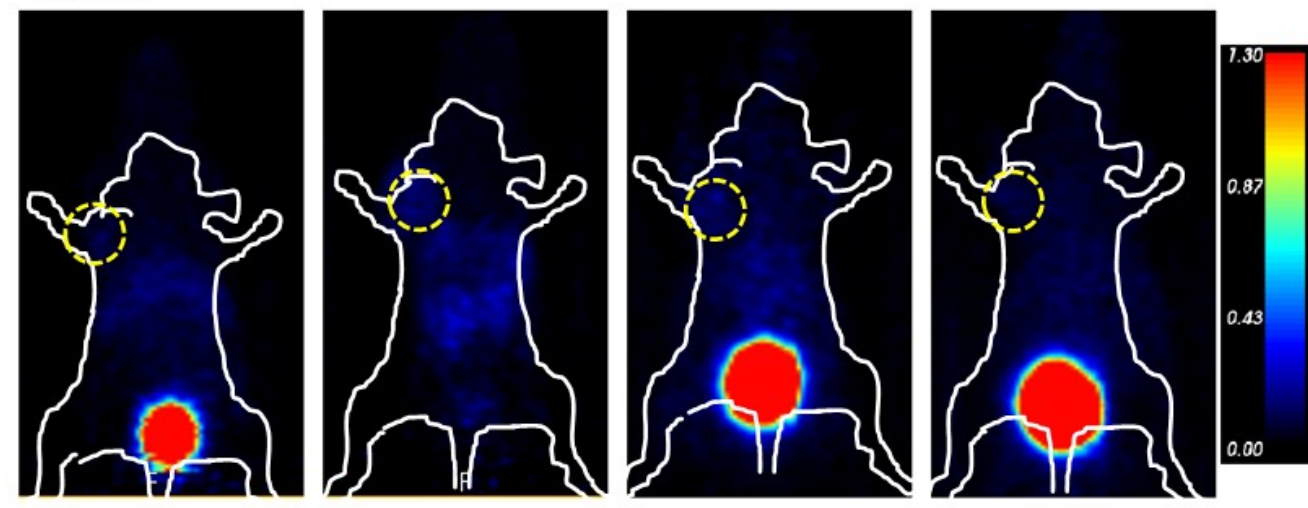

${ }^{68}$ Ga-P122
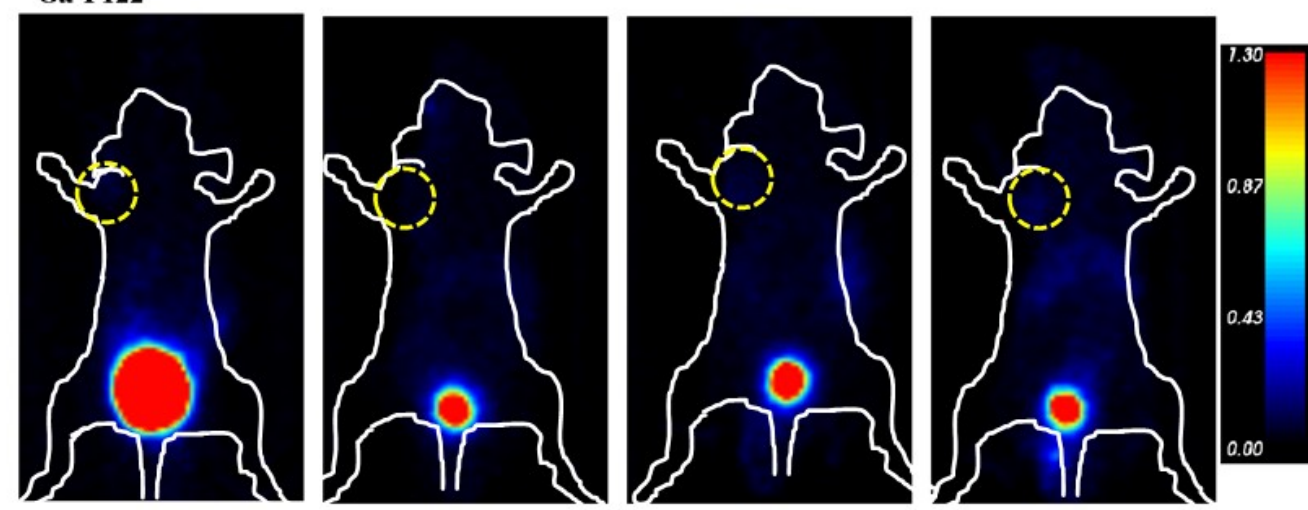

${ }^{68} \mathrm{Ga}-\mathrm{P} 124$
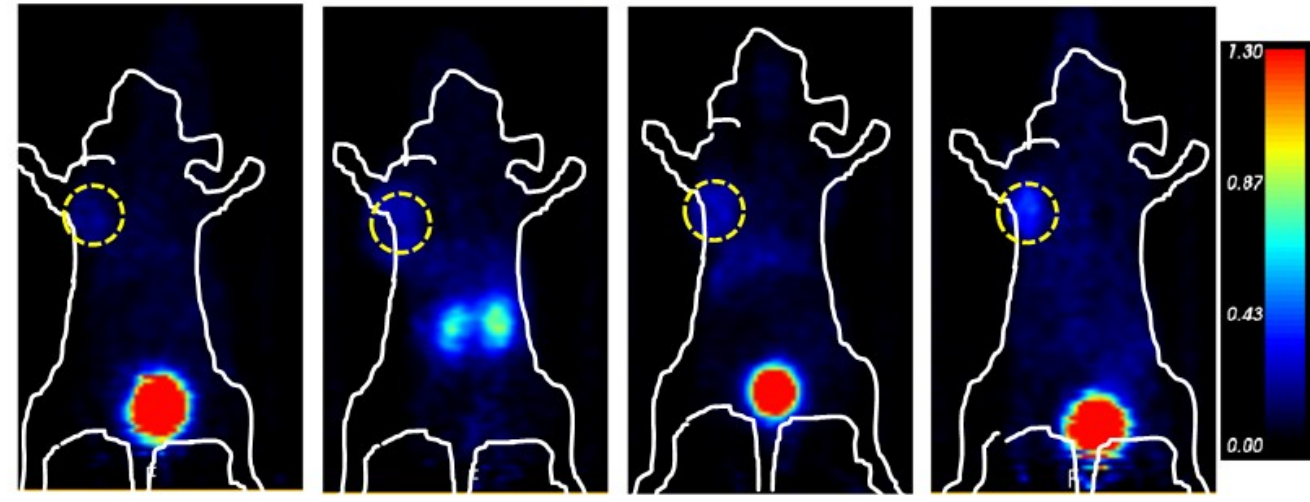


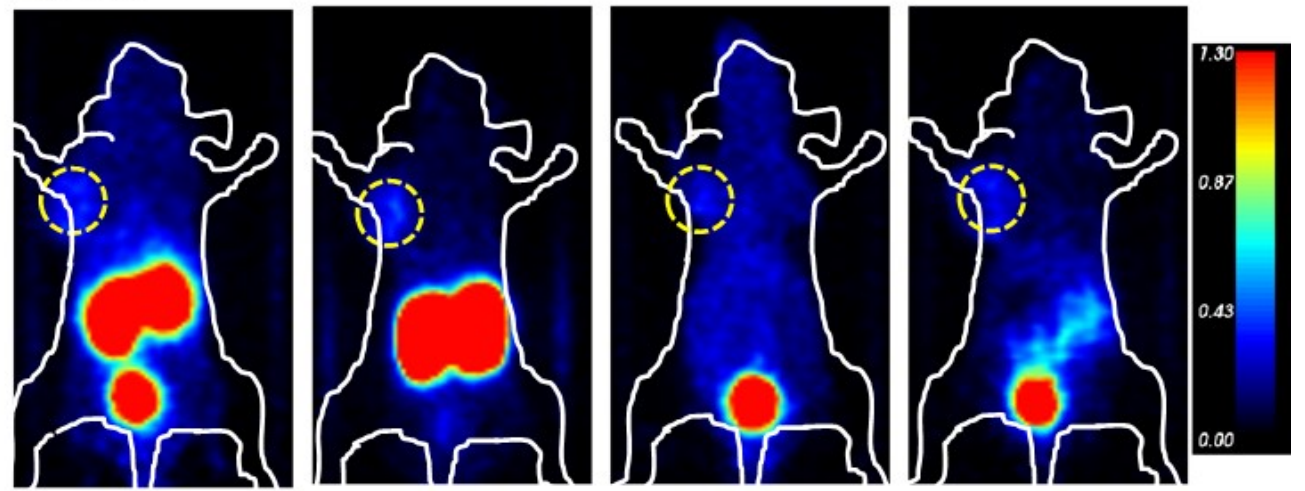

${ }^{68}$ Ga-P125

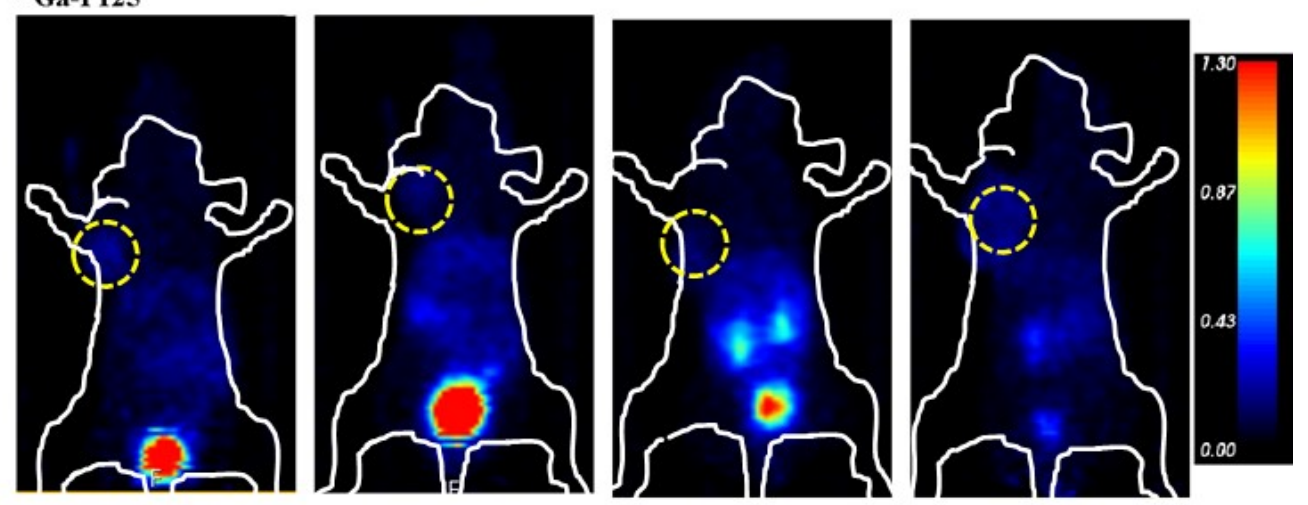

${ }^{68} \mathrm{Ga}-\mathrm{P} 126$

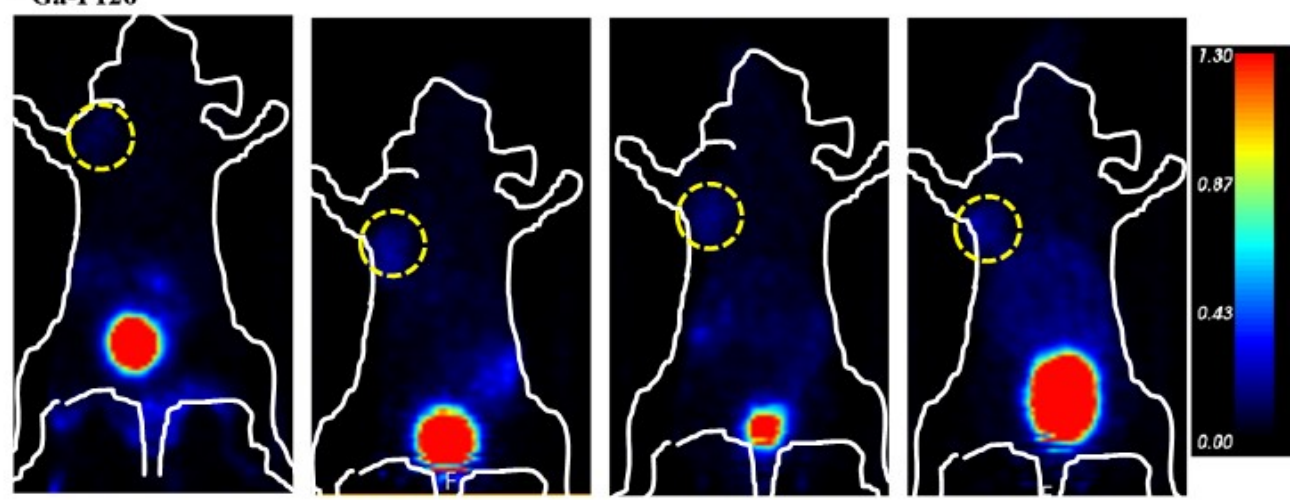

${ }^{68}$ Ga-P136

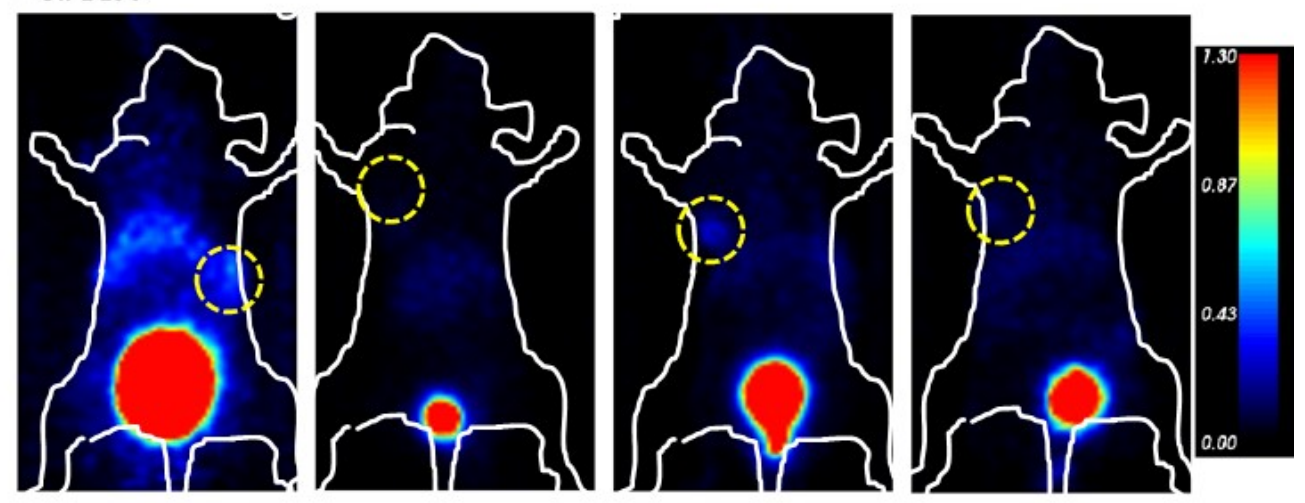


${ }^{68}$ Ga-P137
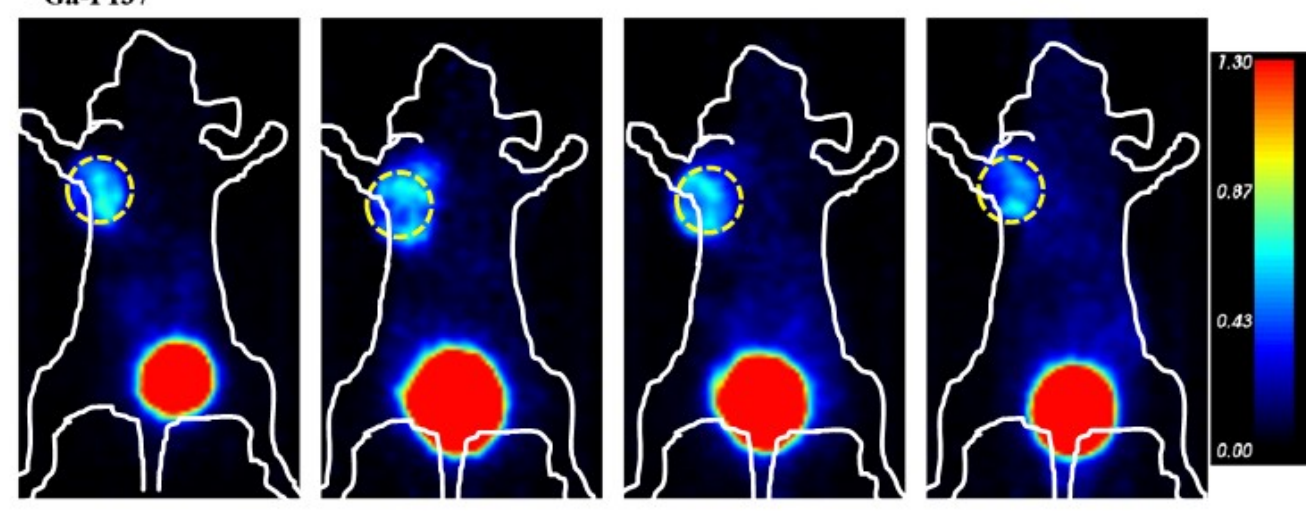

${ }^{68} \mathrm{Ga}-\mathrm{P141}$
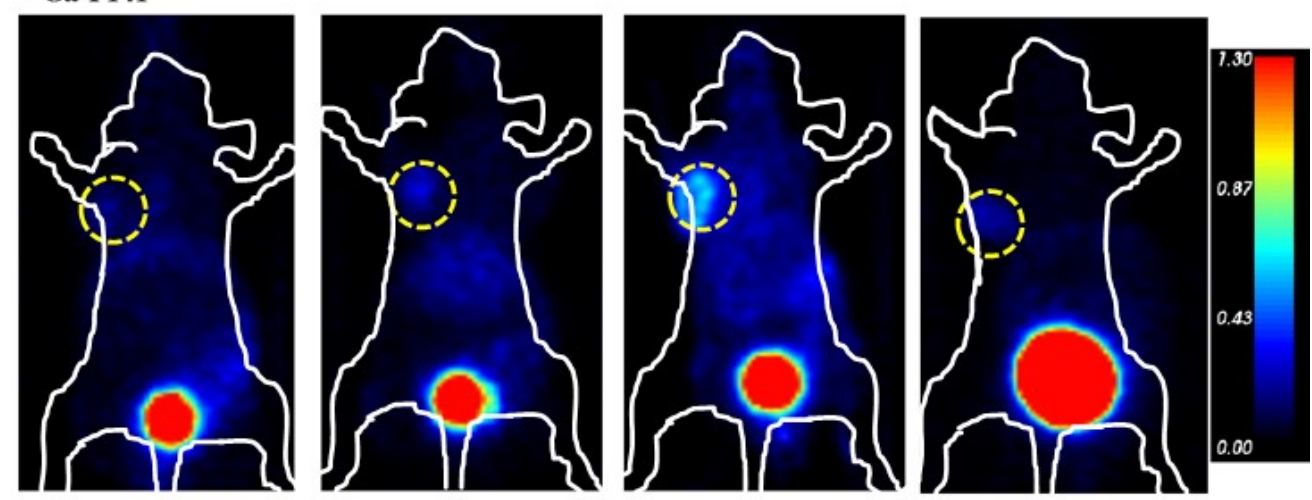

${ }^{68}$ Ga-P143
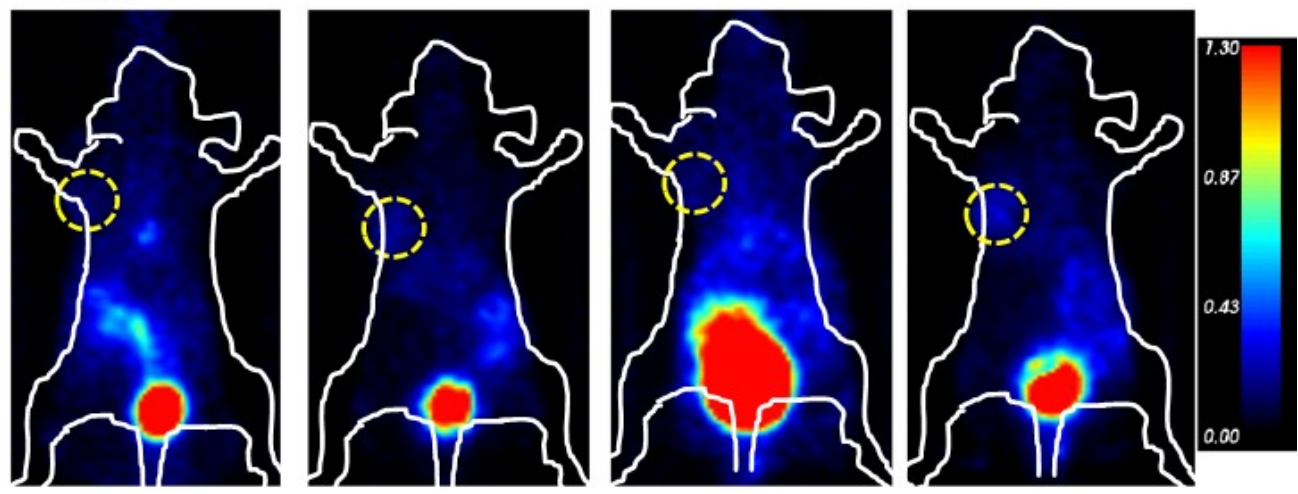

${ }^{68}$ Ga-P144
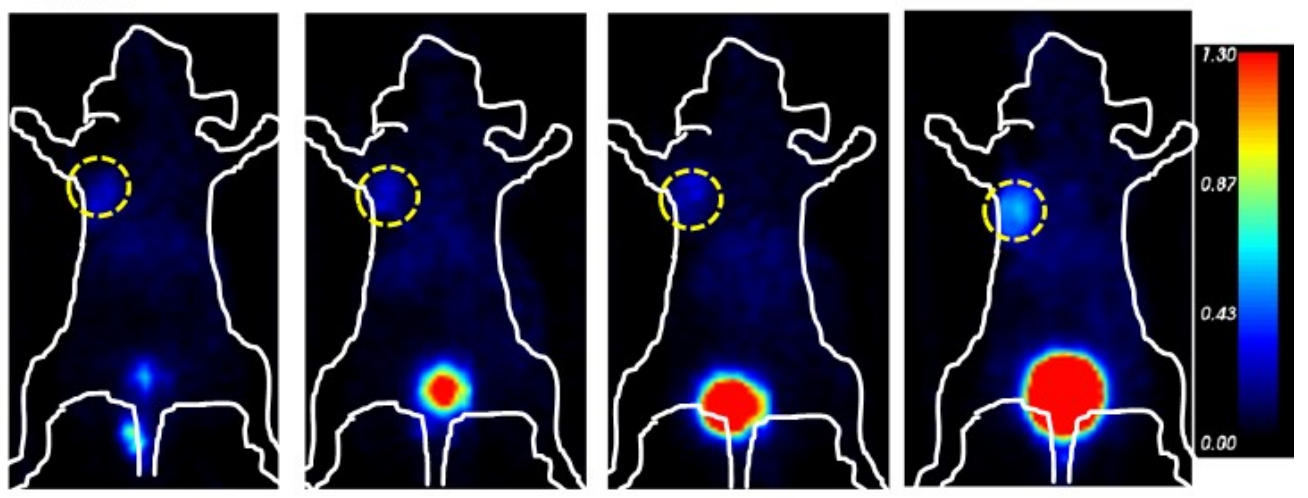


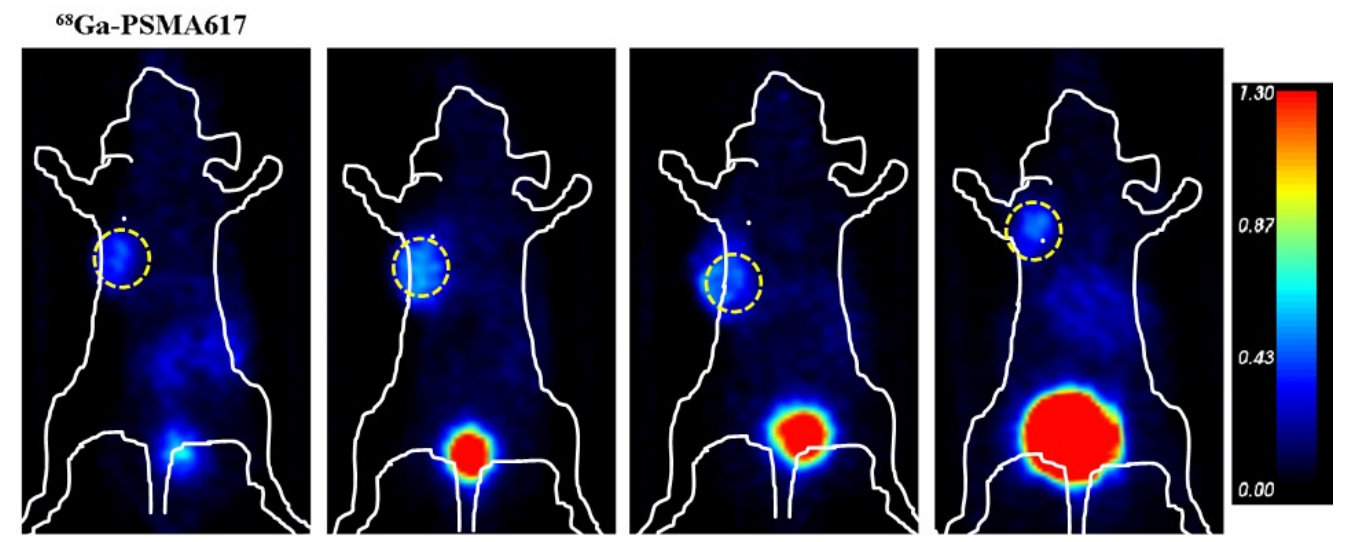

Figure S6. Whole-body coronal slices from MicroPET imaging of Balb/c nu mice bearing 22Rv1 tumor xenografts $(n=4)$.

Table S3. Biodistribution of $\left[{ }^{68} \mathrm{Ga}\right] \mathrm{Ga}-\mathrm{P} 137$ in Balb/c nu mice bearing PSMA-positive 22Rv1 tumors (mean $\pm \mathrm{SD}, \mathrm{n}=4, \% \mathrm{ID} / \mathrm{g}$ )

\begin{tabular}{|c|c|c|c|c|c|}
\hline \multirow{2}{*}{ Tissues } & \multicolumn{4}{|c|}{$\left[{ }^{68} \mathrm{Ga}\right] \mathrm{Ga}-\mathrm{P} 137$} & \multirow{2}{*}{$\begin{array}{c}{\left[{ }^{68} \mathrm{Ga}\right] \mathrm{Ga}-} \\
\text { PSMA-617 } \\
60 \mathrm{~min}\end{array}$} \\
\hline & $30 \mathrm{~min}$ & $60 \mathrm{~min}$ & $120 \mathrm{~min}$ & $\begin{array}{l}60 \mathrm{~min} \\
\text { blocked }\end{array}$ & \\
\hline Heart & $0.87 \pm 0.50$ & $0.37 \pm 0.08$ & $0.29 \pm 0.04$ & $0.41 \pm 0.11$ & $0.22 \pm 0.12$ \\
\hline Liver & $0.92 \pm 0.16$ & $0.52 \pm 0.13$ & $0.48 \pm 0.09$ & $0.63 \pm 0.10$ & $0.34 \pm 0.05$ \\
\hline Lung & $2.13 \pm 0.70$ & $1.00 \pm 0.26$ & $0.55 \pm 0.08$ & $1.03 \pm 0.37$ & $0.50 \pm 0.10$ \\
\hline Kidney & $26.00 \pm 17.86$ & $6.04 \pm 2.16$ & $3.57 \pm 1.03$ & $1.77 \pm 0.68^{* *}$ & $5.17 \pm 1.37$ \\
\hline Spleen & $1.06 \pm 0.16$ & $0.58 \pm 0.17$ & $0.35 \pm 0.02$ & $0.57 \pm 0.25$ & $0.39 \pm 0.10$ \\
\hline Stomach & $0.54 \pm 0.22$ & $0.26 \pm 0.12$ & $0.18 \pm 0.06$ & $0.33 \pm 0.24$ & $0.17 \pm 0.08$ \\
\hline Muscle & $0.71 \pm 0.20$ & $0.30 \pm 0.20$ & $0.19 \pm 0.09$ & $0.45 \pm 0.10$ & $0.13 \pm 0.05$ \\
\hline Large intestine & $0.71 \pm 0.14$ & $0.61 \pm 0.37$ & $0.68 \pm 0.31$ & $0.51 \pm 0.07$ & $0.32 \pm 0.18$ \\
\hline Small intestine & $0.63 \pm 0.15$ & $0.35 \pm 0.12$ & $0.20 \pm 0.04$ & $0.64 \pm 0.10$ & $0.15 \pm 0.01$ \\
\hline Tumor & $5.69 \pm 1.11$ & $6.43 \pm 0.98$ & $6.91 \pm 2.07$ & $1.13 \pm 0.33 * *$ & $3.41 \pm 1.31$ \\
\hline Brain & $0.11 \pm 0.04$ & $0.08 \pm 0.03$ & $0.06 \pm 0.02$ & $0.08 \pm 0.04$ & $0.05 \pm 0.02$ \\
\hline Blood & $2.24 \pm 0.87$ & $0.91 \pm 0.17$ & $0.71 \pm 0.06$ & $1.00 \pm 0.14$ & $0.49 \pm 0.13$ \\
\hline Tumor/Muscle & $8.74 \pm 3.80$ & $26.97 \pm 13.39$ & $44.42 \pm 21.32$ & $2.65 \pm 1.16$ & $29.61 \pm 14.54$ \\
\hline Tumor/Blood & $2.94 \pm 1.51$ & $6.73 \pm 1.48$ & $9.62 \pm 2.42$ & $1.19 \pm 0.36$ & $6.97 \pm 2.24$ \\
\hline
\end{tabular}

**P: Data showed significant different from $\left[{ }^{68} \mathrm{Ga}\right] \mathrm{Ga}-\mathrm{P} 137$ without blocking at 60 min postinjection, $P<0.01$. 


\section{Stability of $\left[{ }^{68} \mathrm{Ga}\right] \mathrm{Ga}-\mathrm{P} 137$}
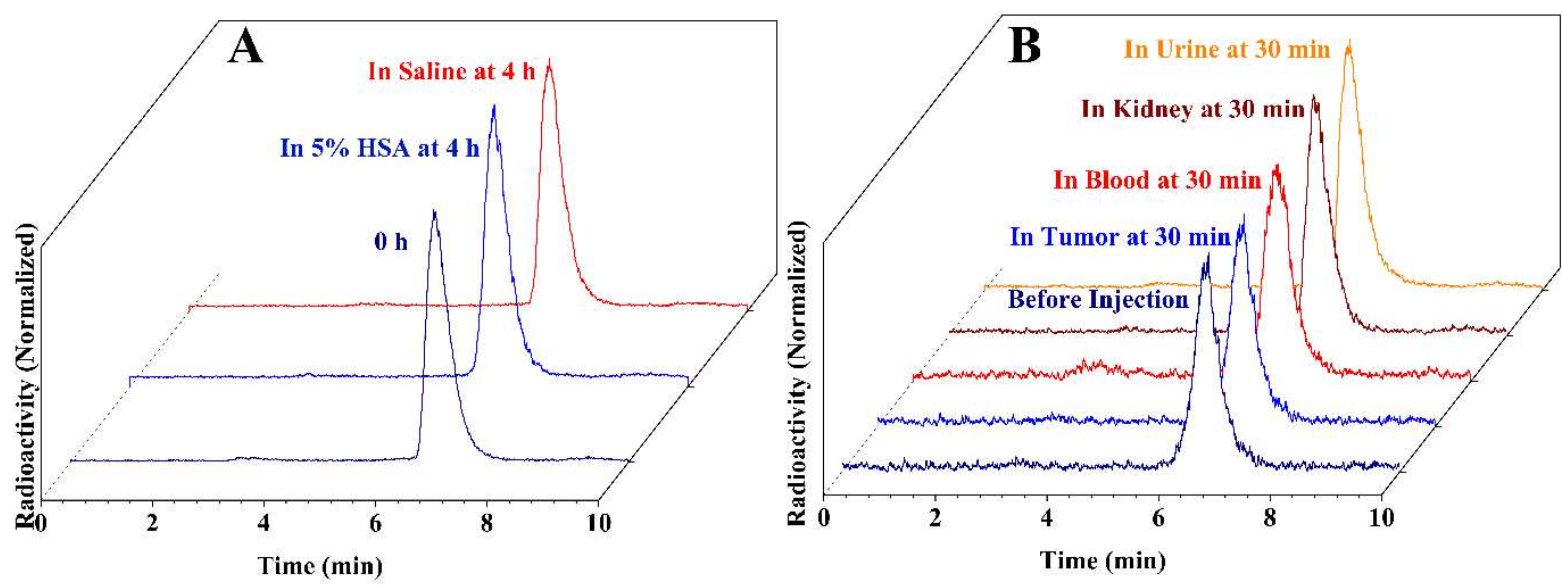

Figure S7. Stability of $\left[{ }^{68} \mathrm{Ga}\right] \mathrm{Ga}-\mathrm{P} 137$. (A) HPLC patterns of $\left[{ }^{68} \mathrm{Ga}\right] \mathrm{Ga}-\mathrm{P} 137$ in saline and in $5 \%$ HSA at $4 \mathrm{~h}$. (B) HPLC patterns of $\left[{ }^{68} \mathrm{Ga}\right] \mathrm{Ga}-\mathrm{P} 137$ in tumor, blood, kidney and urine at $30 \mathrm{~min}$ postinjection.

\section{Toxicity test}

In order to verify the toxicity of DOTA-ODAP ligand, we conducted an toxicity test on P137 according to the Chinese Pharmacopoeia (2020 edtion). 18-22g Kunming mice were selected and randomly grouped, 5 mice as the test group and 3 mice as the control group, and the weights of the mice were recorded before the test. The experimental group was injected with $0.5 \mathrm{mg} / 0.5 \mathrm{ml} \mathrm{P} 137$ solution ( $25 \mathrm{mg} / \mathrm{kg}, 167,000$ times the dose administered to humans) through the tail vein of mice, and the control group was injected with the same volume of saline. The mice were observed for 2 days including diet, respiration, activity, defecation, skin and pain sensation and other indicators. In order to verify the toxicity of ${ }^{68} \mathrm{Ga}-\mathrm{P} \mathbf{1 3 7}, 5$ Kunming mice (18-22 g) were used in the test with 3 mice as the control group, and the weights of the mice were recorded before the test. The experimental group was injected with $37 \mathrm{MBq} / 0.2 \mathrm{ml}{ }^{68} \mathrm{Ga}-\mathrm{P} 137$ solution $(1233 \mathrm{MBq} / \mathrm{kg}$, 330 times the dose administered to humans) through the tail vein of mice, and the control group was injected with the same volume of saline. The mice were observed for 7 days including diet, respiration, activity, defecation, skin and pain sensation and other indicators. During the observation period, all the animals were alive and have no abnormal reactions. 


\section{SUV of translational PET/CT Imaging}

Table S4. Data of $\left[{ }^{68} \mathrm{Ga}\right] \mathrm{Ga}-\mathrm{P} 137$ and $\left[{ }^{68} \mathrm{Ga}\right] \mathrm{Ga}-\mathrm{PSM} 4617$ in patients

\begin{tabular}{|c|c|c|c|c|c|c|c|}
\hline \multirow[b]{2}{*}{ Tissues(SUVmax) } & \multicolumn{2}{|c|}{ Patient 1} & \multicolumn{2}{|c|}{ Patient 2} & \multicolumn{2}{|c|}{ Patient 3} & \multirow{2}{*}{$\begin{array}{c}\text { SUVmax }\left(\left[{ }^{68} \mathrm{Ga}\right] \mathrm{Ga}-\right. \\
\text { P137)/ SUVmax } \\
\left(\left[{ }^{68} \mathrm{Ga}\right] \mathrm{Ga}-\mathrm{PSMA}-617\right)\end{array}$} \\
\hline & $\begin{array}{c}{\left[{ }^{68} \mathrm{Ga}\right] \mathrm{Ga}-} \\
\mathrm{P} 137\end{array}$ & $\begin{array}{c}{\left[{ }^{68} \mathrm{Ga}\right] \mathrm{Ga}-} \\
\text { PSMA-617 }\end{array}$ & $\begin{array}{c}{\left[{ }^{68} \mathrm{Ga}\right] \mathrm{Ga}-} \\
\text { P137 }\end{array}$ & $\begin{array}{l}{\left[{ }^{68} \mathrm{Ga}\right] \mathrm{Ga}-} \\
\text { PSMA-617 }\end{array}$ & $\begin{array}{c}{\left[{ }^{68} \mathrm{Ga}\right] \mathrm{Ga}-} \\
\mathrm{P} 137\end{array}$ & $\begin{array}{c}{\left[{ }^{68} \mathrm{Ga}\right] \mathrm{Ga}-} \\
\text { PSMA-617 }\end{array}$ & \\
\hline Lacrimal Gland & 7.2 & 8.2 & 8.4 & 12.1 & 5.8 & 4.3 & $0.97 \pm 0.34$ \\
\hline Parotid Gland & 11.7 & 10.6 & 16.6 & 16.5 & 9.6 & 6.9 & $1.17 \pm 0.20$ \\
\hline Submandibular Gland & 12.6 & 11.0 & 14.5 & 18.2 & 13.0 & 9.5 & $1.10 \pm 0.29$ \\
\hline Liver & 5.2 & 4.9 & 6.3 & 5.6 & 5.9 & 5.9 & $1.06 \pm 0.06$ \\
\hline Kidney & 27.4 & 26.8 & 21.9 & 26.2 & 27.4 & 30.8 & $0.92 \pm 0.10$ \\
\hline Spleen & 6.7 & 5.8 & 11.7 & 12.5 & 7.1 & 6.9 & $1.04 \pm 0.11$ \\
\hline Bladder & 2.4 & 11.2 & 13.2 & 50.4 & 2.4 & 20.1 & $0.20 \pm 0.07$ \\
\hline Muscle & 0.7 & 0.8 & 0.9 & 0.8 & 0.7 & 0.8 & $0.96 \pm 0.14$ \\
\hline \multicolumn{8}{|l|}{ Cancer lesion } \\
\hline Primary PCa & 9.1 & 11.1 & -- & -- & 12.4 & 10.8 & \\
\hline Bone metastasis 1 & -- & -- & -- & -- & 6.3 & 3.9 & \\
\hline Bone metastasis 2 & -- & -- & -- & -- & 6.2 & 4.8 & \\
\hline Lymph node metastasis1 & -- & -- & 12.2 & 14.5 & -- & -- & $0.97 \pm 0.32$ \\
\hline Lymph node metastasis2 & -- & -- & 13.2 & 19.3 & -- & -- & \\
\hline Lymph node metastasis3 & -- & -- & 28.5 & 31.0 & -- & -- & \\
\hline Lymph node metastasis4 & -- & -- & 22.6 & 30.1 & -- & -- & \\
\hline Lymph node metastasis5 & -- & -- & 13.1 & 19.1 & -- & -- & \\
\hline
\end{tabular}


Figures
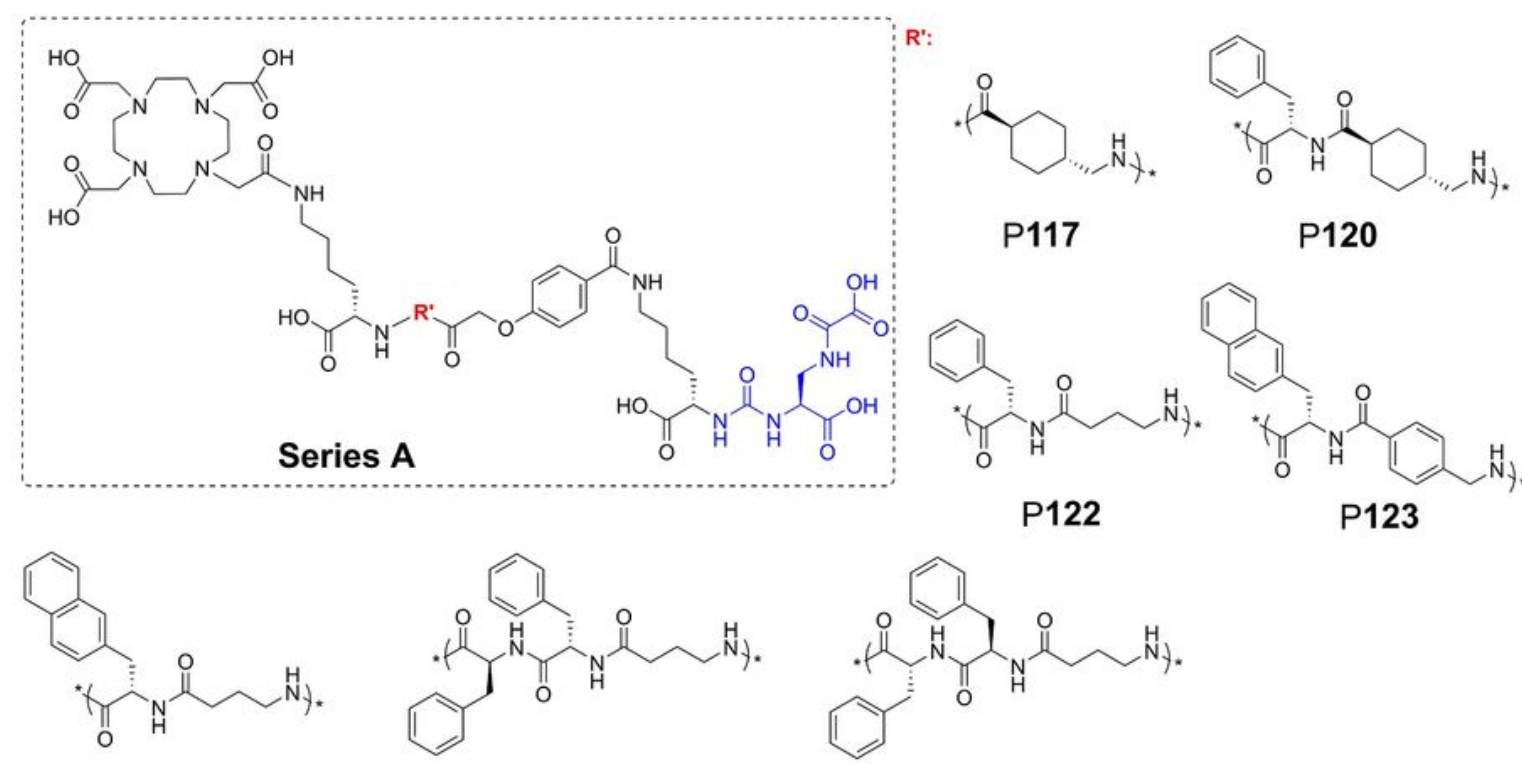

P124

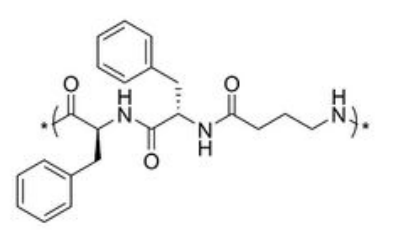

P125

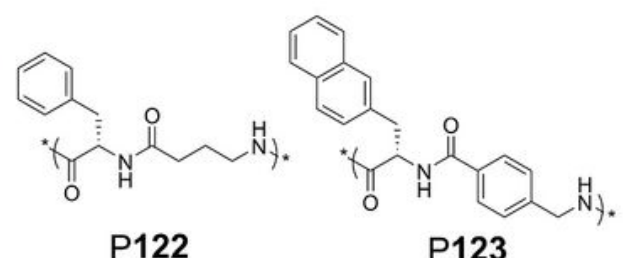

P122

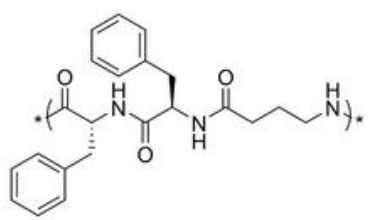

P126

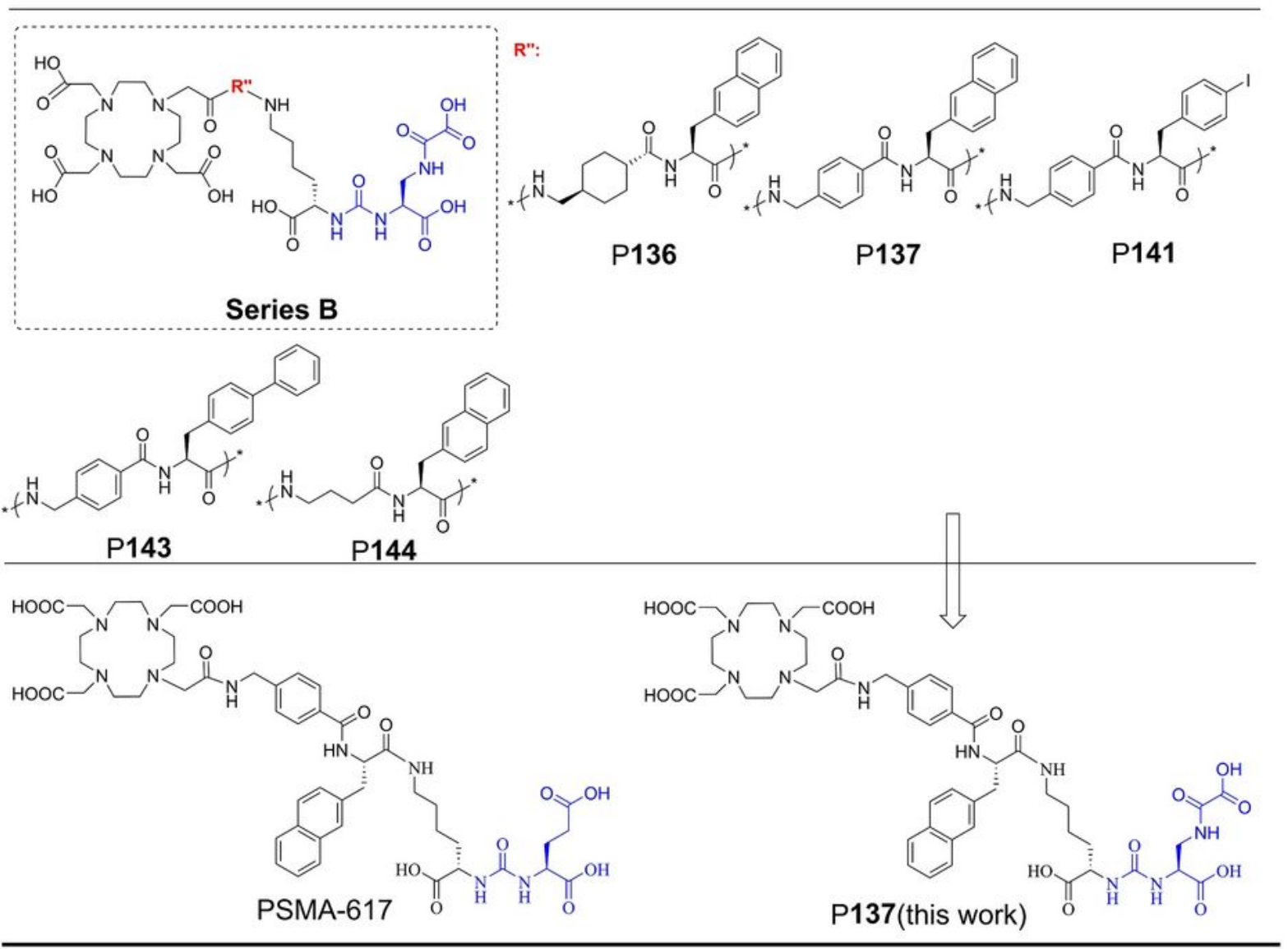

Figure 1

please see the manuscript file for the full caption 


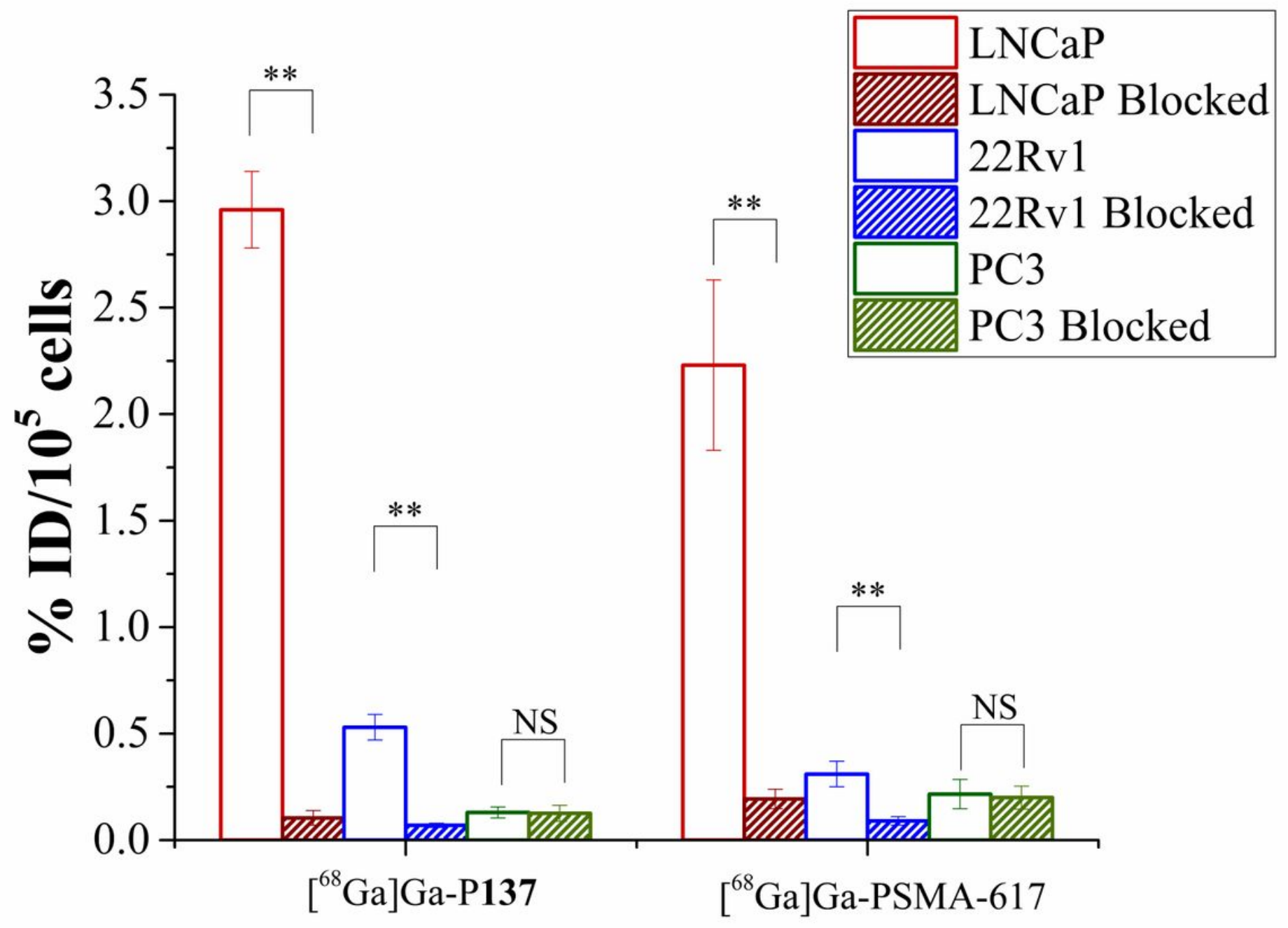

Figure 2

please see the manuscript file for the full caption 

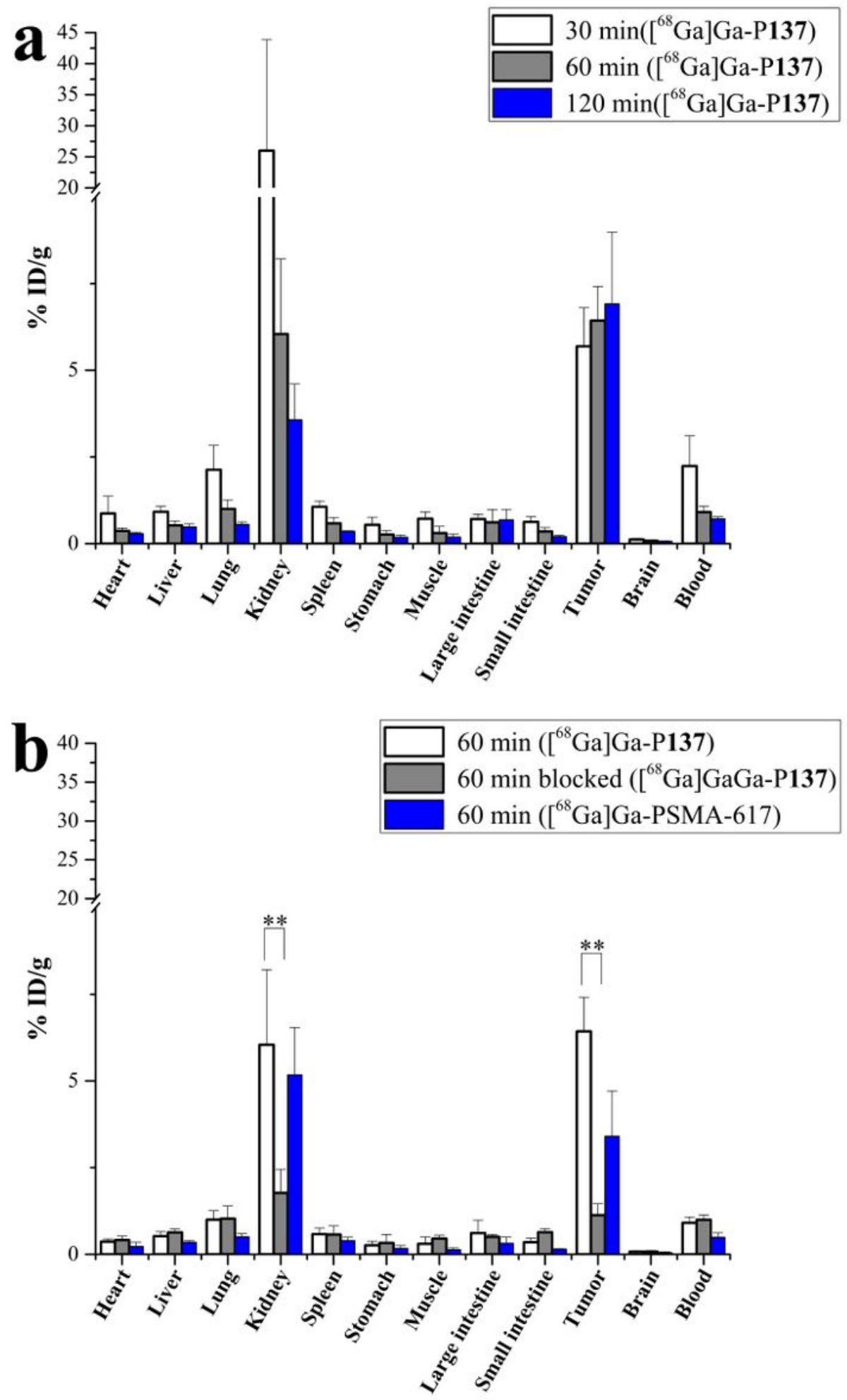

Figure 3

please see the manuscript file for the full caption 

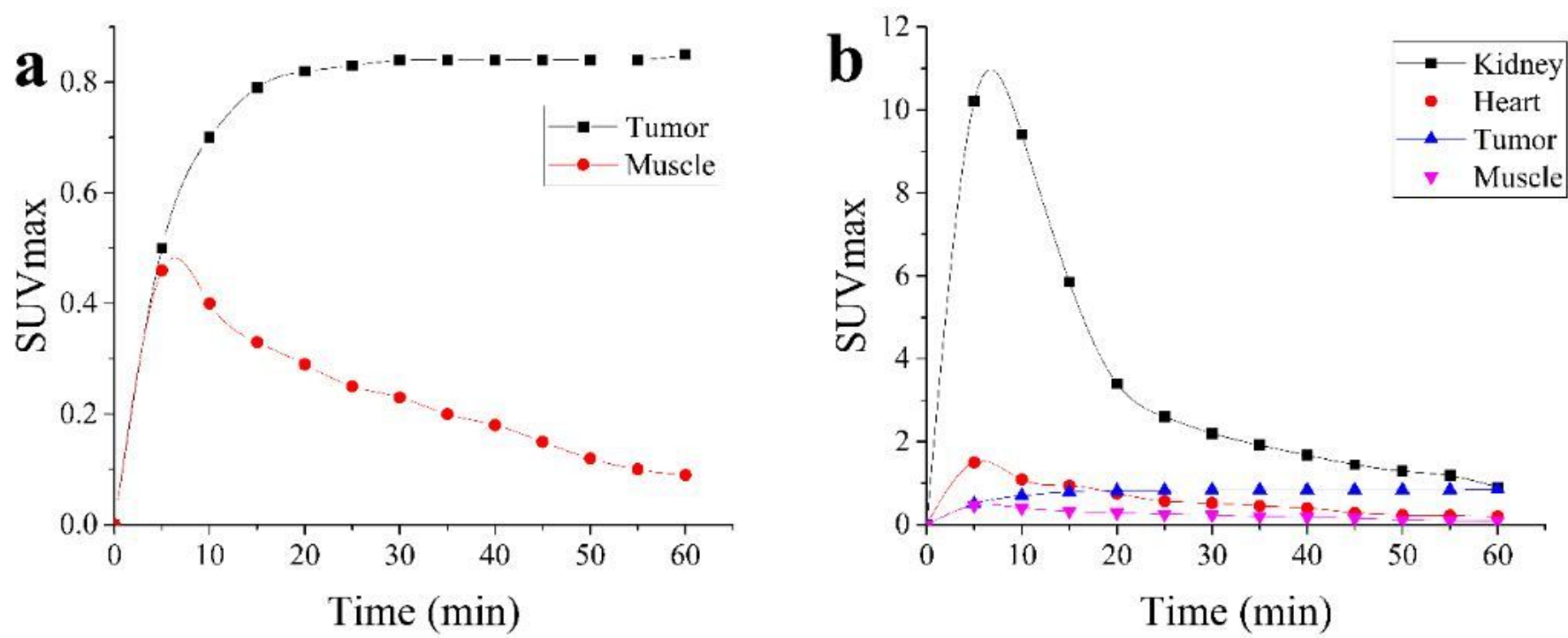

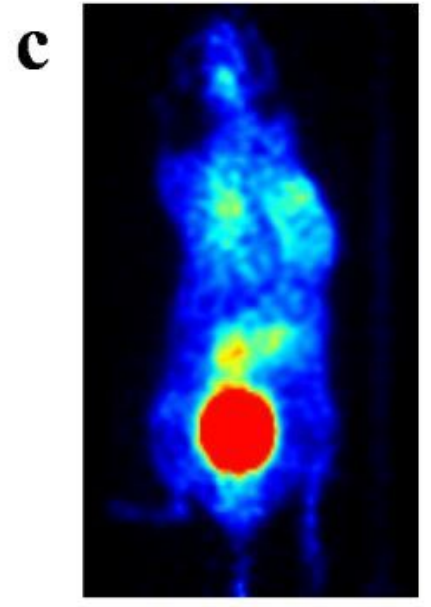

$10-15 \mathrm{~min}$

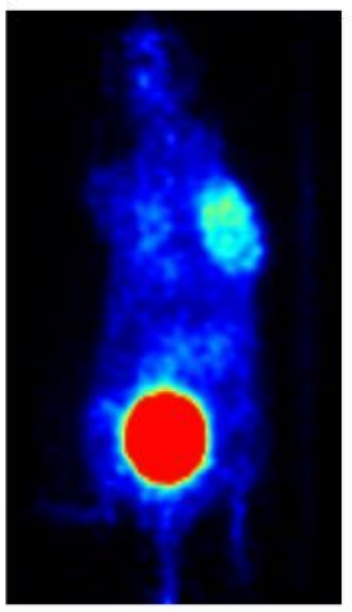

25-30 min

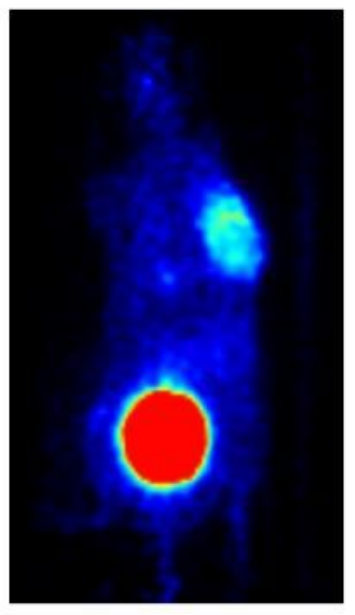

$40-45 \mathrm{~min}$

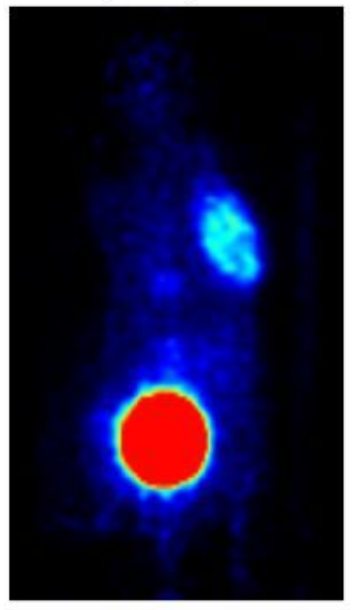

$55-60 \mathrm{~min}$

Figure 4

please see the manuscript file for the full caption 


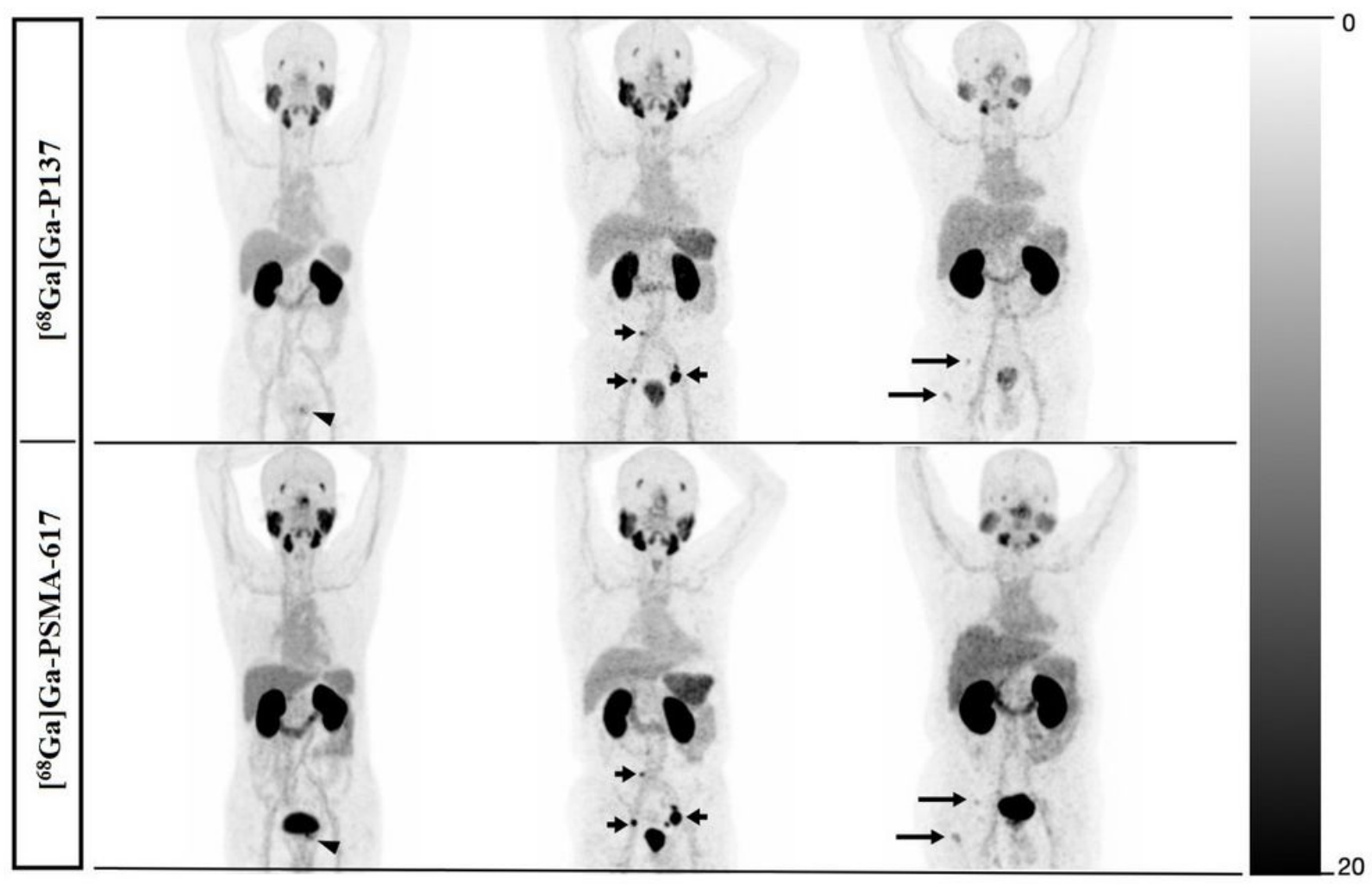

Figure 5

please see the manuscript file for the full caption

\section{Supplementary Files}

This is a list of supplementary files associated with this preprint. Click to download.

- tables.pdf

- P137EJNMMISI20210325.pdf 